\title{
Sociometric Status of Participants Involved in School Bullying
}

\author{
Marcela Almeida Zequinão ${ }^{1}$ \\ Pâmella de Medeiros ${ }^{1}$ \\ Jorge Luiz da Silva ${ }^{2}$ \\ Beatriz Oliveira Pereira ${ }^{3}$ \\ Fernando Luiz Cardoso
}

\begin{abstract}
The situation of social vulnerability hinders the integration processes and thus can foster problems in interpersonal interactions in school. This study aimed to analyze the sociometric status and its relationships with sex, age and profiles of bullying participation in children and adolescents in situations of social vulnerability. A total of 409 students between the third and seventh grades of two public elementary schools in Florianópolis-SC participated in this study. The positive status was higher for boys $(M=11.07 ; S D=8.52)$ and adolescents $(M=11.46 ; S D=8.19)$ compared to girls $(M=8.55 ; S D=5.60)$ and children $(M=8.83 ; S D=6.56)$. The aggressors' positive status was higher, with significant difference, compared to victims and non-participants of bullying $(p=0.008)$. In the context of bullying, aggressors' high status can collaborate to their use of violence in conflict resolution or to gain peer popularity.
\end{abstract}

Keywords: bullying, status, victimization, vulnerability, sociometry

\section{Status Sociométrico de Participantes Envolvidos em Bullying Escolar}

Resumo: A situação de vulnerabilidade social dificulta os processos de integração e com isso pode fomentar problemas nas interações interpessoais na escola. Este estudo objetivou analisar o status sociométrico e as suas relações com o sexo, a idade e os perfis de participação no bullying em crianças e adolescentes em situação de vulnerabilidade social. Participaram 409 estudantes do terceiro ao sétimo anos do Ensino Fundamental de duas escolas públicas de Florianópolis-SC. O status positivo foi maior para os meninos $(M=11,07 ; D P=8,52)$ e os adolescentes $(M=11,46 ; D P=8,19)$ em relação às meninas $(M=8,55 ; D P=5,60)$ e às crianças $(M=$ $8,83 ; D P=6,56)$. O status positivo dos agressores foi maior, com diferença significativa, em relação às vítimas e não participantes no bullying $(p=0,008)$. No contexto do bullying, o status elevado dos agressores pode colaborar para que eles utilizem a violência na solução de conflitos ou para obtenção de popularidade entre os pares.

Palavras-chave: bullying, status, vitimização, vulnerabilidade, sociometria

\section{Estatus Sociométrico de Participantes Involucrados en el Bullying en la Escuela}

Resumen: La situación de vulnerabilidad social dificulta los procesos de integración, lo que puede ocasionar problemas en las interacciones interpersonales en la escuela. Este estudio tuvo como objetivo analizar el estatus sociométrico y sus relaciones con el sexo, la edad y los perfiles de participación en el bullying en niños y adolescentes en situación de vulnerabilidad social. Participaron 409 estudiantes del $3 .^{\circ}$ al $7 .^{\circ}$ grados de la educación primaria de dos escuelas públicas en Florianópolis (SC, Brasil). El estatus positivo fue mayor para los chicos $(M=11,07 ; D E=8,52)$ y los adolescentes $(M=11,46 ; D E=8,19)$ en comparación con las chicas $(M=8,55$; $D E=5,60)$ y los niños $(M=8,83 ; D E=6,56)$. El estatus positivo de los agresores fue mayor, con una diferencia significativa, que el de las víctimas y los no participantes en el bullying $(p=0,008)$. El estatus elevado de los agresores en el bullying puede colaborar con la utilización de la violencia para resolver conflictos o ganar popularidad entre sus pares.

Palabras clave: bullying, niveles, victimización, vulnerabilidade, sociometría

${ }^{1}$ Universidade do Estado de Santa Catarina, Florianópolis-SC, Brazil

${ }^{2}$ Universidade de Franca, Franca-SP, Brazil

${ }^{3}$ Universidade do Minho, Braga, Portugal

This article is derived from the master's thesis of the first author under the supervision of the latter, defended in 2013, in the Graduate Program in Human Movement Science of the Santa Catarina State University - UDESC.

Correspondence address: Marcela Almeida Zequinão. Universidade do Estado de Santa Catarina. Rua Paschoal Simone, 358, Florianópolis-SC, Brazil. CEP 88.035-001. E-mail: marcelazequinao@gmail.com
The status an individual presents before his peers is a striking feature in power disputes in social relations (Anderson \& Kilduff, 2009). The measurement of status can be performed with the sociometric status, which concerns the prestige, prominence and respect that individuals achieve in their social groups (Anderson, Kraus, Galinsky, \& Keltner, 2012), the position they occupy in the society and also how they perceive themselves inserted in this society, or the position or condition of an individual in the social hierarchy 
(Hoffman, Hamm, \& Farmer, 2015). Sociometry, developed by Jacob Levy Moreno, proposes to investigate, to quantify and to qualify interpersonal relationships, aiming to the social and dynamics of the groups. Therefore, it represents an important method in the studies of identification of sociometric status in different contexts, for it is able to measure relationships that often cannot be perceived by a direct look (Moreno, 1994).

In the school environment, the sociometric status is especially relevant for children and adolescents, since acceptance, rejection, number of friends, among other aspects, represent indicators of the quality of students'social interactions in learning and recreation activities (Bearman, Martinez, Stice, \& Presnell, 2006). Thus, differences in students' status affect the quality of their relationships with classmates. One of the problems identified in peer relations due to status is the power imbalance. In some cases, this imbalance results in aggressive behaviors, and may then promote a phenomenon called by the international literature as bullying (Sekol, 2013). The bullying is a kind of peer violence characterized by the repeatability of aggression over time, by intentionality to hurt themselves or to cause suffering to another and by the imbalance of power between the parties involved (Rocha, Costa, \& Passos Neto, 2013).

This peer-to-peer violence may also constitute a coercive strategy practiced with the intention of establishing and maintaining higher positions in the group's social hierarchy, since subjects viewed with more status by peers tend to be leaders in the group (Pronk, Goossens, Olthof, De Mey, \& Willemen, 2013). The occurrence of bullying is considered quite common among children and adolescents. It is estimated that between $10 \%$ and $30 \%$ of school children worldwide are involved in some of its forms of manifestation (Lucas-Molina, Williamson, Pulido, \& Calderón, 2014; Rettew \& Pawlowski, 2016). In Brazil, according to the National School Health Survey (Pesquisa Nacional de Saúde do Escolar-PeNSE), conducted in 2012 with a sample of 109,104 students from public and private schools in the 27 Brazilian states, $7.2 \%$ of participants were victims of bullying and $20.8 \%$ were aggressors (Oliveira et al., 2016). However, independently on the prevalence of participation in bullying, it is known that the simple involvement in this phenomenon brings several difficulties in the development of children and adolescents, with negative consequences in short- and long-term (Khamis, 2015).

The relationship between sociometric status and the way students participate in bullying has been widely discussed in the literature, with no consensus among researchers. For some authors, a high status is achieved by those who demonstrate their value to peers and act in order to enable the proper functioning of their social group, raising the well-being of its members (Anderson et al., 2012; Kraus et al., 2014). In this perspective, dominant behaviors by coercive and aggressive means can impair the individual's image in the group, reducing their peers' respect. Thus, in situations of bullying, aggressors and victims tend not to be appreciated by colleagues, and the aggressor is often censured by the group members for their coercive behavior (Anderson \& Kilduff, 2009; Hafen, Laursen, Nurmi, \& Salmela-Aro, 2013; Kraus et al., 2014).

In contrast, other authors indicate that, in certain contexts, behavioral difficulties, which includes the practice of violence, do not harm the status, but they are associated with popularity, because they constitute socially valued behaviors (Caravita, Sijtsema, Rambaran, \& Gini, 2014; Lansu \& Cillessen, 2015). In these specific contexts, children and adolescents with behavioral problems consider themselves as more included in games, they do not suffer mockery and are more popular (Stevanato, Loureiro, Linhares, \& Marturano, 2003). This is a worrying relationship, to the extent such children and adolescents can resist modifying their aggressive behaviors, even if these behaviors are considered problematic for parents and teachers, which may favor the occurrence of more bullying (Levandoski \& Cardoso, 2013).

However, what can be perceived as a consensus between both sides is that the status consists of a collective judgment, in which the group defines the individual's degree of hierarchy, being the one with the highest status who presents behaviors consistent with the specific norms and expectations of the social context (Anderson \& Kilduff, 2009; Kraus et al., 2014). But, which context would it be? If the context is strongly presented in the literature as fundamental to understand the sociometric status, how to define a pattern? How to determine what is considered good or bad in children's perception without analyzing the context first?

In Brazil, several metropolitan cities present children and adolescents living in an unfavorable social context, characterizing themselves in a situation of social vulnerability. Thus, there are localities or regions marked by higher levels of social inequality, which access services with lower quality, where the inhabitants are in a situation of social vulnerability, the definition of which corresponds "to the condition of not possess or not to being able to use material and immaterial assets that would enable the individual or social group to deal with the poverty situation" (Stoco \& Almeida, 2011, p. 665). This vulnerability is complex and multifaceted, it exceeds the issues of health, social life, educational contexts, symbolic organizations, ethnic issues, work fields, as well as public policies in general, with regard to living conditions and social support (Guareschi, Reis, Huning, \& Bertuzzi, 2007).

The situation of vulnerability hinders the processes of social integration and, therefore, it can foster problems in social interactions in school and the increase in situations of conflict, violence and bullying (Pinheiro \& Williams, 2009). Thus, this study discuss the context as the problematic, aiming to analyze the sociometric status and its relationships with sex, age and profiles of participation in bullying in children and adolescents in situations of social vulnerability. 


\section{Method}

\section{Participants}

The World Health Organization (WHO) considers a child the individual up to nine years of age and adolescent those aged between 10 and 19 years. Thus, the participants of this study were children and adolescents between the third and seventh grades of elementary school, of both sexes, enrolled in two municipal public schools. As this study is part of a large-scale project, which involves the use of several other instruments, only these school grades were selected to participate in the research so that the age group accepted in all the instruments used was respected.

In terms of characterization, the participants were aged between eight and 16 years, mean age of 11.1 years for boys $(n=207)$ and 10.9 years for girls $(n=202)$, which can be justified by the fact that most belonged to more advanced grades, referring to the sixth and seventh grades $(52.8 \%)$, and many participants have already failed some grade in school (48.5\% of boys and $40.0 \%$ of girls). The students' school mobility was equivalent for both sexes, with mean frequency of 2.5 schools for boys and 2.4 schools for girls. The changes in residence also presented similarities, mean of 1.8 changes for both sexes. Regarding skin color, boys declared themselves Caucasian (68.6\%), black (25.6\%) and brown (5.8\%). Girls declared themselves: Caucasian (73.3\%), black (24.7\%) and brown (2.0\%).

\section{Instruments}

The Subjective Scale of Social Status in Classroom was used to assess the status, an instrument used to assess the status according to colleagues' perception, by sociometric method (Levandoski \& Cardoso, 2013). The instrument is composed of six questions, three referring to the perception of a positive status and three related to a negative status: 1 = "If you had to set up a team in physical education class, who would be the first to be chosen?"; 2 = "If you had to set up a team in physical education class, who would be the last to be chosen?"; 3 = "In your class, who are the strongest colleagues, physically speaking?" 4 = "In your class, who are the weakest colleagues, physically speaking?"; 5 = "If you need help to perform activities and exercises in the classroom, who would be the first to be chosen?"; 6 = "If you need help to perform activities and exercises in the classroom, who would be the last to be chosen?". Based on these questions, a positive status score (sum of the number of times the student was mentioned in questions 1, 3 and 5) and a negative status score (sum of the number of times the student was mentioned in questions 2, 4 and 6) for each participant were estimated.

The Olweus Questionnaire (1996) was used to obtain information regarding the school bullying. Two questions of this instrument were used to define the profiles of participation in bullying. The first question aimed to identify how many times in the last three months of class the participant had been bullied: 1 = "How many times did any student of the school do something wrong to you in the last three months of class?" Whereas the second questioned how many times the participant had been the aggressor: 2 = "How many times did you harm other students at school in the last three months of class?"

Although some studies classify as victims and aggressors those who answered "once or twice," considering that bullying is characterized by a set of systematic and repetitive aggressive attitudes, and occasional aggression cannot be characterized as an episode of bullying, in this study were considered only those who reported to be involved in the phenomenon "three or more times." With the information obtained by those who reported that they were victims and aggressors three or more times, a variable "aggressor-victim" was created, thus classifying the students into 4 categories of participation in bullying: "non-participant," "victim," "aggressor" and "aggressor-victim."

The internal reliability of the instruments was calculated based on the data obtained in this research using all the instruments. Thus, the Subjective Scale of Social Status in the Classroom and the Olweus Questionnaire presented a moderate and good level of internal consistency, with Cronbach's alphas equal to 0.606 and 0.750 , respectively.

\section{Procedure}

Data collection. This cross-sectional study with intentional sampling was conducted in the metropolitan area of Florianópolis-SC, between February and December 2012. The Secretariat of Education of the municipality indicated the two selected schools because they participate in a social project that framed them in the profile of social vulnerability proposed by the study. After this selection, all students between the $3^{\text {rd }}$ and $7^{\text {th }}$ grade were invited to participate in the study, however, only those who delivered the Consent Form signed by the parents or guardians were selected. The only exclusion criterion adopted was those participant presenting some intellectual disability that prevented the understanding of the instruments, based on the indication of Special School Care (Atendimento Escolar Especial-AEE) of schools.

The sample estimation assumed 0.5 alpha and $50 \%$ power. The minimum number expected was 316 participants, however, the size of the final sample was 409 participants. Upon delivery of the consent form signed by the children's parents or guardians, all participants were present individually in the two stages of data collection. In the first stage, the participants answered a self-report questionnaire about their participation in bullying, whereas the second stage was composed of filling out the sociometric scale on status at school, in which each participant opined on the sociometric status of peers. Both stages were applied and supervised by two researchers trained to clarify any questions of the participants. When comparing the status with the profiles of participation in bullying, a slight sample loss was identified $(n=16)$, due to the lack of completion of the Olweus Questionnaire or the absence of the participant at this stage of the research. 
Data analysis Data normality was verified using the Kolgomorov-Smirnov test. As the data did not present a normal distribution, the nonparametric tests of MannWhitney $U$ and Kruskal-Wallis were performed for comparison between the groups. The research data were tabulated and analyzed in the Statistical Package for the Social Science (SPSS for Windows) version 20.0. The Bioestat version 5.0 program was also used for Dunn's post hoc in the Kruskal-Wallis analysis of variance test. A $5 \%$ significance level was used in all tests $(p<0.05)$.

\section{Ethical Considerations}

The research project to which this study is linked to was approved by the Research Ethics Committee of the Santa Catarina State University (UDESC) (Process 5439/2011). Prior to data collection, participants and their guardians received detailed information about the research. Only the students who expressed willingness to collaborate with the investigation and who presented the free and informed consent for - FICF signed by a guardian, as well as the Informed Assent signed by participants over the age of 12 years participated in the study.

\section{Results}

When comparing the status in relation to the sex of participants, it was identified that boys were more often chosen preferably in physical education classes, they were also more often cited as the strongest and weakest, besides being the last to be chosen for in-pairs activities performed in classroom, when compared to girls. On the other hand, the girls were more often cited as the preferred ones to do in-pairs activities. Significant differences between the sexes were also identified regarding the positive status score, with boys presenting a higher status in colleagues' perception. However, when adding the questions that refer to a worse status, the boys were also the most often indicated as presenting lower status in the colleagues' perception, when compared to girls (Table 1).

In relation to the differences in sociometric status among children and adolescents, it was found that adolescents were cited more often as the first, but also as the last chosen in physical education classes. The adolescents were also considered the strongest and the last to be chosen for classroom activities, as well as also presenting both higher positive status score, and higher negative status score (Table 2).

The aggressors were more often chosen by colleagues in physical education classes, differing significantly from those who do not participate in the bullying and from the victims. On the other hand, the aggressor-victims were the least chosen in physical education classes, when compared to those who do not participate in the bullying. There were also significant differences between the profiles of participation in the bullying and the variable "last to be chosen for classroom activities", with a tendency for aggressors to be the most indicated in this issue, when compared to those who do not participate. Regarding the sociometric status scores, significant differences were found in the positive sociometric status, with aggressors presenting higher status when compared to those who do not participate and the victims (Table 3 ).

Table 1

Differences between sex in relation to sociometric status

\begin{tabular}{|c|c|c|c|c|}
\hline & $\begin{array}{c}\text { Boys } \\
(n=207)\end{array}$ & $\begin{array}{c}\text { Girls } \\
(n=202)\end{array}$ & $U$ & $p$ \\
\hline & $M(S D)$ & $M(S D)$ & & \\
\hline First to be chosen at physical education & $5.37(4.12)$ & $4.24(2.79)$ & 16260.00 & 0.013 \\
\hline Last to be chosen at physical education & $3.05(2.39)$ & $2.55(2.03)$ & 16904.00 & 0.055 \\
\hline Strongest & $3.55(4.33)$ & $1.17(1.85)$ & 11100.00 & 0.001 \\
\hline Weakest & $2.73(2.64)$ & $2.02(2.14)$ & 15889.50 & 0.004 \\
\hline First to be chosen for classroom activities & $2.14(2.04)$ & $3.15(2.33)$ & 14044.50 & 0.001 \\
\hline Last to be chosen for classroom activities & $2.97(2.38)$ & $1.63(1.59)$ & 12417.50 & 0.001 \\
\hline Positive status score & $11.07(8.52)$ & $8.55(5.60)$ & 16185.50 & 0.011 \\
\hline Negative status score & $8.75(5.50)$ & $6.20(4.52)$ & 13223.00 & 0.001 \\
\hline
\end{tabular}

Note. *number of times mentioned by colleagues (range 0-30 - depending on how many students each class had); $M=$ mean; $S D=$ Standard deviation; $U=$ Mann-Whitney $U$ test; $p=$ significance level. 
Table 2

Differences between children and adolescents in relation to the sociometric status

\begin{tabular}{|c|c|c|c|c|}
\hline & $\begin{array}{l}\text { Children } \\
(n=255)\end{array}$ & $\begin{array}{l}\text { Adolescents } \\
(n=154)\end{array}$ & $U$ & $p$ \\
\hline & $M(S D)$ & $M(S D)$ & & \\
\hline First to be chosen at physical education & $4.51(3.51)$ & $5.30(3.61)$ & 14905.50 & 0.008 \\
\hline Last to be chosen at physical education & $2.58(2.19)$ & $3.17(2.25)$ & 14710.50 & 0.004 \\
\hline Strongest & $1.58(2.28)$ & $3.68(4.69)$ & 11705.50 & $<0.001$ \\
\hline Weakest & $2.49(2.47)$ & $2.17(2.34)$ & 16113.00 & 0.119 \\
\hline First to be chosen for classroom activities & $2.74(2.37)$ & $2.48(2.01)$ & 17096.50 & 0.531 \\
\hline Last to be chosen for classroom activities & $2.06(2.00)$ & $2.71(2.30)$ & 14826.00 & 0.006 \\
\hline Positive status score & $8.83(6.56)$ & $11.46(8.19)$ & 13929.50 & $<0.001$ \\
\hline Negative status score & $7.13(5.22)$ & $8.05(5.10)$ & 15432.50 & 0.030 \\
\hline
\end{tabular}

Note. *number of times mentioned by colleagues (range 0-30 - depending on how many students each class had); $M=$ mean; $S D=$ Standard deviation; $U=$ Mann-Whitney $\mathrm{U}$ test; $p=$ significance level.

Table 3

Differences between bullying participation profiles in relation to sociometric status

\begin{tabular}{|c|c|c|c|c|c|}
\hline & $\begin{array}{c}\text { Does not } \\
\text { participate } \\
(n=275)\end{array}$ & $\begin{array}{l}\text { Victim } \\
(n=67)\end{array}$ & $\begin{array}{l}\text { Aggressor } \\
(n=32)\end{array}$ & $\begin{array}{c}\text { Aggressor } \\
\text { victim }(n=19)\end{array}$ & $p$ \\
\hline & $M(S D)$ & $M(S D)$ & $M(S D)$ & $M(S D)$ & \\
\hline First to be chosen for classroom activities & $2.53(2.26)$ & $2.72(2.31)$ & $3.39(2.04)$ & $2.58(2.19)$ & 0.117 \\
\hline Last to be chosen for classroom activities & $2.02^{\mathrm{a}}(1.94)$ & $2.52(2.10)$ & $3.00^{\mathrm{b}}(2.44)$ & $2.84(2.52)$ & 0.044 \\
\hline First to be chosen at physical education & $4.58^{\mathrm{a}}(3.37)$ & $4.17^{\mathrm{a}}(2.82)$ & $6.77^{\mathrm{b}}(4.56)$ & $4.79(2.30)$ & 0.016 \\
\hline Last to be chosen at physical education & $2.57^{\mathrm{a}}(2.09)$ & $2.67(2.18)$ & $3.03(2.27)$ & $4.00^{\mathrm{b}}(2.08)$ & 0.018 \\
\hline Strongest & $2.18(3.14)$ & $1.78(2.05)$ & $3.06(3.26)$ & $2.21(1.93)$ & 0.233 \\
\hline Weakest & $2.32(2.47)$ & $2.80(2.72)$ & $2.35(1.92)$ & $2.16(1.92)$ & 0.664 \\
\hline Positive status score & $4.58^{\mathrm{a}}(3.37)$ & $4.17^{\mathrm{a}}(2.82)$ & $6.77^{\mathrm{b}}(4.56)$ & $4.79(2.30)$ & 0.008 \\
\hline Negative status score & $2.02(1.94)$ & $2.67(2.18)$ & $3.03(2.27)$ & $4.00(2.08)$ & 0.083 \\
\hline
\end{tabular}

Note. *number of times mentioned by colleagues (range 0-30 - depending on how many students each class had); $M=$ mean; $S D=$ Standard deviation; $p=$ significance level of the Kruskal Wallis test; ${ }^{\mathrm{a}-\mathrm{b}}=$ Dunn's post hoc.

\section{Discussion}

The aim of this study was to analyze the sociometric status and their relationships with sex, age and profiles of bullying participation in children and adolescents in situations of social vulnerability. The results indicated that, when analyzing the differences between sexes in relation to sociometric status, in almost all questions the boys were more remembered than girls, both for questions about positive and negative status. These results reinforce other studies that indicate boys as more competitive for social dominance and status than girls (Nocentini, Menesini, \& Salmivalli, 2013; Salmivalli, 2010). Moreover, girls can strengthen competitiveness among boys, making them even more aggressive, since for girls the 
aggressor boys are the most popular students in the class and who excel in strength activities and sports skills, whereas victims are seen in a position of lower status (Levandoski \& Cardoso, 2013).

Adolescents presented higher positive and negative status in relation to children, indicating that in adolescence the status is more evidenced and polarized, perhaps because adolescents attribute greater importance to social relations with their peers as well as to the position they occupy in group contexts. In general, the search for greater independence from parental influences contributes to increase the connection between adolescents and their peers and, consequently, they are more subject to colleagues' influences, especially those who are more insecure or present low self-esteem (Santrock, 2014). In this regard, in situations of bullying this can be a problematic aspect, because aggressors' positive status can reinforce the conduct of other students so that they also become aggressors by influence or search for popularity (Silva et al., 2016).

In relation to the profiles of participation in bullying, in the variable "positive status score" a significant difference between the groups occurred, in which the aggressors presented higher positive status score in the perception of colleagues when compared to those who do not participate in bullying and victims, who have lower "positive status score." The aggressors were also the first to be chosen in physical education classes and the last to be chosen for classroom activities. On the other hand, the aggressor-victims were the last to be chosen in physical education. These data reinforce previous studies, in which victimization relates to low status and lower popularity (Chang et al., 2013; Levandoski \& Cardoso, 2013). Other studies are also in agreement with these findings, indicating that the aggressor profile is associated with the perception of higher status, popularity and knowledge of it (Caravita et al., 2014; Chang et al., 2013; Lansu \& Cillessen, 2015; Levandoski \& Cardoso, 2013; Reijntjes et al., 2013).

One possible explanation for aggressors presenting higher sociometric status is that these students already had a high status before becoming aggressors and, when they began the aggression against colleagues, they had greater support from peers due to the popularity they already had. Thus, the high status would represent a precondition for bullying. Another explanation is that the aggressors possibly aggress their colleagues intending to be more popular, feeling more powerful, or getting a good image of themselves (Rocha et al., 2013). Therefore, the search for higher sociometric status would represent one of the causes for bullying. Levandoski and Cardoso (2013) identified the aggressor boys as the most popular students in the classroom and who excelled in strength activities and sports skills. In opposition, the victims were perceived in a lower position of sociometric status. This generates greater difficulties to combat bullying, considering that aggressors, despite being on a path of problematic development, may consider that short-term personal advantages overcome disadvantages, thus refusing to change their aggressive behaviors.

In relation to interactions specifically outside the classroom, involving more dynamic activities such as physical activities in physical education classes, it is known that children and adolescents who have a wide motor repertoire are coveted as game partners, being those who know how to run fast, catch a ball well and be agile, the best seen by their social group (Weineck, 2000). Thus, success in physical activities and the involvement in school-age sports are responsible for increased popularity, as well as they restrict the possibilities of peer intimidation at school (Peguero, 2008).

In this study, when analyzing the aspects related to sociometric status in physical education classes, it was identified that the aggressors were indicated as those chosen first for sports and games, when compared to the victims. Moreover, the aggressor-victims were more often chosen last. This information reinforces other studies that indicate aggressors as those who participate the most in sport activities in colleagues' view, as well as indicates that students with low skills for the dominant games in current society are excluded by the peers, whereas those who fit the most tend to stand out socially (Levandoski \& Cardoso, 2013).

The social position can exert influence on those involved in bullying, acting in a way to defer the action of aggressors and victims in this process (Griffiths, Wolke, Page, \& Horwood, 2006). These influences were evident in the profiles assumed by the participants of this study, considering that when analyzing the sociometric status of children and adolescents, very specific characteristics among victims and aggressors were verified. This kind of information is also relevant to discourage situations of aggression, both in classrooms and in sports practices.

The aggressor-victims were indicated as the last chosen in activities proposed in physical education classes, they also presented a high level of rejection in classroom activities, highlighting the low popularity of this group and identifying an important issue when comparing these findings with other studies that did not identify the highest status of aggressors (Anderson \& Kilduff, 2009; Hafen et al., 2013). In the studies mentioned, however, the aggressor-victims were not highlighted from the rest of the participants, which may have hindered the results interpretation, for this group of students is, in fact, the one which presents greater social problems and the worst results in psychosocial adjustment assessments, consequently generating a low sociometric status between peers (Kochel, Ladd, Bagwell, \& Yabko, 2015).

Notably, in the studies by Kraus et al. (2014), in which no elevated status in aggressors were found, children were analyzed in a context of "fun," and not properly in bullying behaviors. Similarly, in the study by Hafen et al. (2013) the authors state that the study was carried out in a homogeneous, stable and prosperous region of northern Europe, thus failing to justify generalizations for young people of other ages living in different circumstances, such as in the case of children and adolescents in situations of social vulnerability of this study.

The high status of aggressor students is worrisome, since children and adolescents who participate or witness situations of violence at school may comprehend this violence from a normative point of view, as being appropriate to conflict resolution or to obtain popularity and prestige among peers (Senra, Lourenço, \& Pereira, 2011). This can help aggressors, by 
realizing their high status before their colleagues, to understand this circumstance as a positive support to their behavior, and then they may engage even more aggressive acts against their classmates.

This study contributes to the literature in psychology about peer violence at school because it presents the sociometric status of students as one of the important variables for understanding the profile of participation in bullying of children and adolescents. In this perspective, this study indicated that the status represents a variable that surpasses financial conditions for determining the social hierarchy between a homogeneous peer group, since all participants in this study were in a condition of social vulnerability and, despite this, variations in their status were shown. This result may be a starting point for the preparation of interventions aimed to prevent or to reduce the school bullying, considering the distinctions in status presented by victims, aggressors, aggressors-victims and non-participants in bullying situations.

Despite the contributions of this study about the relationship between sociometric status and participation in bullying situations, especially considering the scarcity of productions on these themes, some limitations must be highlighted. The cross-sectional design prevents the fulfillment of inferences about the direction of the identified relationships, not enabling the establishment of causalities. Future research may adopt longitudinal design, since this design enables the monitoring of changes that occur over time, in order to identify the effects exerted by the sociometric status on involvement in bullying situations and vice versa thus identifying cause and effect relationships.

Another limitation occurred because the situation of social vulnerability of the participants was not directly assessed, with only the criteria adopted by the social program they participated. Similarly, data were not collected from other groups of students who did not present social vulnerability, which limited the interpretation of results, because information from the literature was exclusively used. It is emphasized the importance of more studies aimed to address these limitations so that they can make clearer the relationship between sociometric status and bullying, aiming to use this direct measure and to obtain more accurate data to support the prevention efforts and confront these two themes in schools.

\section{References}

Anderson, C.,\&Kilduff, G.J.(2009). The pursuitofstatusin social groups. Current Directions in Psychological Science, 18(5), 295-298. doi:10.1111/j.1467-8721.2009.01655.x

Anderson, C., Kraus, M. W., Galinsky, A. D., \& Keltner, D. (2012). The local-ladder effect: Social status and subjective well-being. Psychological Science, 23(7), 764-771. doi:10.1177/0956797611434537
Bearman, S. K., Martinez, E., Stice, E., \& Presnell, K. (2006). The skinny on body dissatisfaction: A longitudinal study of adolescent girls and boys. Journal of Youth and Adolescence, 35(2), 217-229. doi:10.1007/s10964-0059010-9

Caravita, S. C., Sijtsema, J. J., Rambaran, J. A., \& Gini, G. (2014). Peer influences on moral disengagement in late childhood and early adolescence. Journal of Youth and Adolescence, 43(2), 193-207. doi:10.1007/s10964-0139953-1

Chang, F. C., Lee, C. M., Chiu, C. H., Hsi, W. Y., Huang, T. F., \& Pan, Y. C. (2013). Relationships among cyberbullying, school bullying, and mental health in Taiwanese adolescents. Journal of School Health, 83(6), 454-462. doi:10.1111/josh. 12050

Griffiths, L. J., Wolke, D., Page, A. S., \& Horwood, J. P. (2006). Obesity and bullying: Different effects for boys and girls. Archives of Disease in Childhood, 91(2), 121-125. doi:10.1136/adc.2005.072314

Guareschi, N. M. F., Reis, C. D., Huning, S. M., \& Bertuzzi, L. D. (2007). Intervenção na condição de vulnerabilidade social: Um estudo sobre a produção de sentidos com adolescentes do programa do trabalho educativo [An intervention in the social vulnerability condition: A study on the meaning production with adolescents from the "trabalho educativo" program]. Estudos e Pesquisas em Psicologia, 7(1), 1-11. Retrieved from http://pepsic.bvsalud.org/scielo. php?script=sci_arttext\&pid=S1808-42812007000100003

Hafen, C. A., Laursen, B., Nurmi, J. E., \& Salmela-Aro, K. (2013). Bullies, victims, and antipathy: The feeling is mutual. Journal of Abnormal Child Psychology, 41(5), 801809. doi:10.1007/s10802-013-9720-5

Hoffman, A. S., Hamm, J. V., \& Farmer, T. W. (2015). Teacher attunement: Supporting early elementary students' social integration and status. Journal of Applied Developmental Psychology, 39, 14-23. doi:10.1016/j.appdev.2015.04.007

Khamis, V. (2015). Bullying among school-age children in the greater Beirut area: Risk and protective factors. Child Abuse \& Neglect, 39, 137-146. doi:10.1016/j.chiabu.2014.08.005

Kochel, K. P., Ladd, G. W., Bagwell, C. L., \& Yabko, B. A. (2015). Bully/victim profiles' differential risk for worsening peer acceptance: The role of friendship. Journal of Applied Developmental Psychology, 41, 38-45. doi:10.1016/j. appdev.2015.05.002

Kraus, M. W., Oveis, C., Allison, M. L., Young, R. C., Tauer, J., \& Keltner, D. (2014). Teasing, taunting, and the politics of politeness: High sociometric status is associated with expectation-consistent behavior. PloS One, 9(8), e104737. doi:10.1371/journal.pone.0104737 
Lansu, T. A., \& Cillessen, A. H. (2015). Associations of group level popularity with observed behavior and influence in a dyadic context. Journal of Experimental Child Psychology, 140, 92-104. doi:10.1016/j. jecp.2015.06.016

Levandoski, G., \& Cardoso, F. L. (2013). Imagem corporal e status social de estudantes brasileiros envolvidos em bullying [Body image and social status of Brazilian students involved in bullying]. Revista Latinoamericana de Psicología, 45(1), 135-145. Retrieved from http://www.scielo.org.co/scielo.php?script $=$ sci_ arttext\&pid=S0120-05342013000100010

Lucas-Molina, B., Williamson, A. A., Pulido, R., \& Calderón, S. (2014). Adaptation of the Participant Role Scale (PRS) in a spanish youth sample: Measurement invariance across gender and relationship with sociometric status. Journal of Interpersonal Violence, 29(16), 2904-2930. doi: $10.1177 / 0886260514527822$

Moreno, J. L. (1994). Quem sobreviverá?: Fundamentos da sociometria, psicoterapia de grupo e sociodrama [Who shall survive? Foundations of sociometry group psychotherapy and sociodrama]. Goiânia, GO: Dimensão 3.

Nocentini, A., Menesini, E., \& Salmivalli, C. (2013). Level and change of bullying behavior during high school: A multilevel growth curve analysis. Journal of Adolescence, 36(3), 495-505. doi:10.1016/j. adolescence.2013.02.004

Oliveira, W. A., Silva, M. A. I., Silva, J. L., Mello, F. C. M., Prado, R. R., \& Malta, D. C. (2016). Associations between the practice of bullying and individual and contextual variables from the aggressors' perspective. Jornal de Pediatria, 92(1), 32-39. doi:10.1016/j. jpedp.2015.06.002

Olweus, D. (1996). The revised Olweus bully/victim Questionnaire. Bergen, Norway. Unpublished manuscript.

Peguero, A. A. (2008). Bullying victimization and extracurricular activity. Journal of School Violence, 7(3),71-85. doi:10.1080/15388220801955570

Pinheiro, F. M. F., \& Williams, L. C. A. (2009). Violência intrafamiliar e intimidação entre colegas no ensino fundamental [Family violence and bullying on primary school]. Cadernos de Pesquisa, 39(138), 995-1018. doi:10.1590/S0100-15742009000300015

Pronk, J., Goossens, F. A., Olthof, T., De Mey, L., \& Willemen, A. M. (2013). Children's intervention strategies in situations of victimization by bullying: Social cognitions of outsiders versus defenders. Journal of School Psychology, 51(6), 669-682. doi:10.1016/j. jsp.2013.09.002
Reijntjes, A., Vermande, M., Olthof, T., Goossens, F. A., van de Schoot, R., Aleva, L., \& van der Meulen, M. (2013). Costs and benefits of bullying in the context of the peer group: A three wave longitudinal analysis. Journal of Abnormal Child Psychology, 41(8), 1217-1229. doi:10.1007/s10802-013-9759-3

Rettew, D. C., \& Pawlowski, S. (2016). Bullying. Child and Adolescent Psychiatric Clinics of North America, 25(2), 235-242. doi:10.1016/j.chc.2015.12.002

Rocha, M. O., Costa, C. L. N. A., \& Passos Neto, I. F. (2013). Bullying e o papel da sociedade [Bullying and the role of society]. Caderno de GraduaçãoCiências Humanas e Sociais-UNIT, 1(16), 191-199. Retrieved from https://periodicos.set.edu.br/index. php/cadernohumanas/article/view/534

Salmivalli, C. (2010). Bullying and the peer group: A review. Aggression and Violent Behavior, 15(2), 112120. doi:10.1016/j.avb.2009.08.007

Santrock, J. W. (2014). Adolescência [Adolescence] (S. M. Rosa, Trans., 14th ed.). Porto Alegre, RS: Artmed.

Senra, L. X., Lourenço, L. M., \& Pereira, B. O. (2011). Características da relação entre violência doméstica e bullying: Revisão sistemática da literatura [Characteristics of the relationship between domestic violence and bullying: A systematic review of the literature]. Gerais: Revista Interinstitucional de Psicologia, 4(2), 297-309. Retrieved from http://pepsic.bvsalud.org/scielo.php? script=sci arttext\&pid=S1983-82202011000200011

Sekol, I. (2013). Peer violence in adolescent residential care: A qualitative examination of contextual and peer factors. Children and Youth Services Review, 35(12), 1901-1912. doi:10.1016/j.childyouth.2013.09.006

Silva, J. L., Oliveira, W. A., Braga, I. F., Farias, M. S., Lizzi, E. A. S., Gonçalves, M. F. C., ... Silva, M. A. I. (2016). The effects of a skill-based intervention for victims of bullying in Brazil. International Journal of Environmental Research and Public Health, 13(11), 1042-1052. doi:10.3390/ijerph13111042

Stevanato, I. S., Loureiro, S. R., Linhares, M. B. M., \& Marturano, E. M. (2003). Autoconceito de crianças com dificuldades de aprendizagem e problemas de comportamento [Self- concept of learning disabled and behavior problem children]. Psicologia em Estudo, 8(1), 67-76. doi:10.1590/S141373722003000100009

Stoco, S., \& Almeida, L. C. (2011). Municipal schools of Campinas and sociodemographic vulnerability: First approximations. Revista Brasileira de Educação, 16(48), 663-694. doi:10.1590/S1413-24782011000300008

Weineck, J. (2000). Biologia do esporte [Biology of sport]. Barueri, SP: Manole. 
Marcela Almeida Zequinão is a professor of the Universidade do Estado de Santa Catarina, Florianópolis-SC, Brazil.

Pâmella de Medeiros is a professor of the Universidade do Estado de Santa Catarina, Florianópolis-SC, Brazil.

Jorge Luiz da Silva is a professor of the Universidade de Franca - SP, Brazil.

Beatriz Pereira Oliveira is a professor of the Universidade do Minho, Braga, Portugal.

Fernando Luiz Cardoso is a Professor of the Universidade do Estado de Santa Catarina, Florianópolis-SC, Brazil.

\section{Authors' Contribution:}

All authors contributed substantially to the conception and design of this study, to data analysis and interpretation, and to the manuscript revision and approval of the final version. All the authors assume public responsibility for the content of the manuscript.

Received: Aug. 29, 2017

$1^{\text {st }}$ Revision: May. 24, 2018

Approved: Mar. 29, 2019

How to cite this article:

Zequinão, M. A., Medeiros, P., Silva, J. L., Pereira, B. O., \& Cardoso, F. L. (2020). Sociometric status of participants involved in school bullying. Paidéia (Ribeirão Preto), 30, e3011. doi: http://dx.doi.org/10.1590/1982-4327e3011 